\title{
Dural Injury During Placement of Burrholes- Single Center Study
}

\author{
Pushpa Biswakarma ${ }^{1}$, Punam Limbu', Kaushila Dhimal ${ }^{1}$ \\ ${ }^{1}$ Neurosurgery Operation Theatre, B and C Medical College Teaching Hospital and Research Center, \\ Birtamode, Jhapa. \\ Correspondence: \\ RN Puspha Biswakarma \\ Neurosurgery Operation Theatre, B \& C Medical College and Teaching Hospital \& Research \\ Center,Birtamode,Jhapa,Nepal. \\ Email: pushpa.bishwakarmal@gmail.com \\ Phone: +9779807938544
}

\begin{abstract}
Background and purpose: Dural tear is one of the unpleasant complications for the neurosurgeon during craniotomy. The injury might be outer dural injury or complete dural tear in nature. With the objective to see the frequency of dural injury and to analysis the association factor this study was performed prospectively. Material and method: This is a Prospective analytical study over the duration of 2 months. All the consecutive patients, who operated for neurosurgical pathologies where drill burr was necessary, were included in this study. Association between age, gender, diagnosis category and number of burrs and dural injury was done using Fischer's exact test or correlation whenever necessary.
\end{abstract}

Result: There were total of 19 patients enrolled in the study with mean age of patient in this study was 49.11 (S.D 17.13) years. Majority of them were male (79\%) and head injury (47\%) was the commonest pathology in the study. correlation between number of burr and dural tear was significant Conclusion: There was no significant correlation between age and dural injury. However, significant correlation was seen between number of burr holes made during the procedure with dural injury.

Key words: craniotomy, burr hole, trephination of skull, dural tear during burr hole.

$\mathrm{O}$ pening the skull vault is a common procedure in neurosurgical theater which involves placement of burr followed by cutting bone using craniotome. Dural tear is one of the unpleasant complication for the neurosurgeon during craniotomy. ${ }^{1,2}$ The prevalence of the complication is around $30 \%$ in different literatures. ${ }^{1}$ The injury might be outer dural injury or complete dural tear in nature. ${ }^{1,2,3}$ With the objective to see the frequency of dural injury and to analysis the association factor this study was performed prospectively.

\section{Material and Methods}

Type of study: Prospective analytical study Sampling technique: Non probability consecutive study

Sample size: 19 patients

Duration of study: 2 months

Site of study: B and C Medical College Teaching Hospital and Research Center, Birtamode, Jhapa, Nepal.

35

Date submitted: 20/ 11/2019

Date accepted: 16/12/2019

\section{Data collection and analysis}

All the consecutive patients, who operated for neurosurgical pathologies where drill burr was necessary, were included in this study. Hospital number, name, age, gender, diagnosis category, number of drill burr and injury of the dura were collected in preformed proforma. Age was presented in mean and standard deviation. Gender, diagnosis category, number of burrs and number of injured dura were presented in percentage.

Analysis was done using SPSS 20. Association between age, gender, diagnosis category and number of burrs and dural injury was done using Fischer's exact test or correlation whenever necessary.

\section{Technical note}

This study is a prospective collection of the data of dural injury which was found intraoperatively during the placement of burr. The burr in this study was made using high speed electric drill in its 
standard setting, where rotation per minute (rmp) was 1250 .

\section{Results}

Mean age of patient in this study was 49.11 (S.D 17.13) years. Majority of them were male (79\%) and head injury (47\%) was the commonest pathology in the study (Figure 1 and 2). There were total of 87 number of burr holes made where $6.89 \%$ of the dural injury was noted. There were no cases of complete dural injury during the placement of burr holes, all the cases of dural injury in this study were of outer dural layer only.

Correlation between age and dural tear showed no significant relation. Similarly, association between genders, diagnosis category with dural injury was also not significant (Table 1). However, correlation between number of burr and dural tear was significant (Table 2)

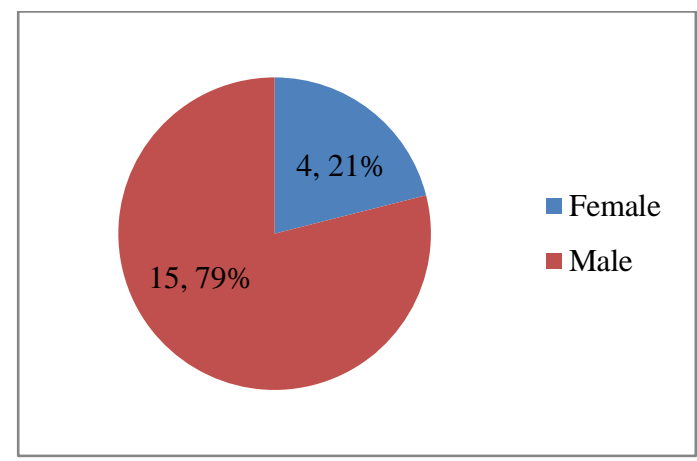

Figure 1: Distribution of gender

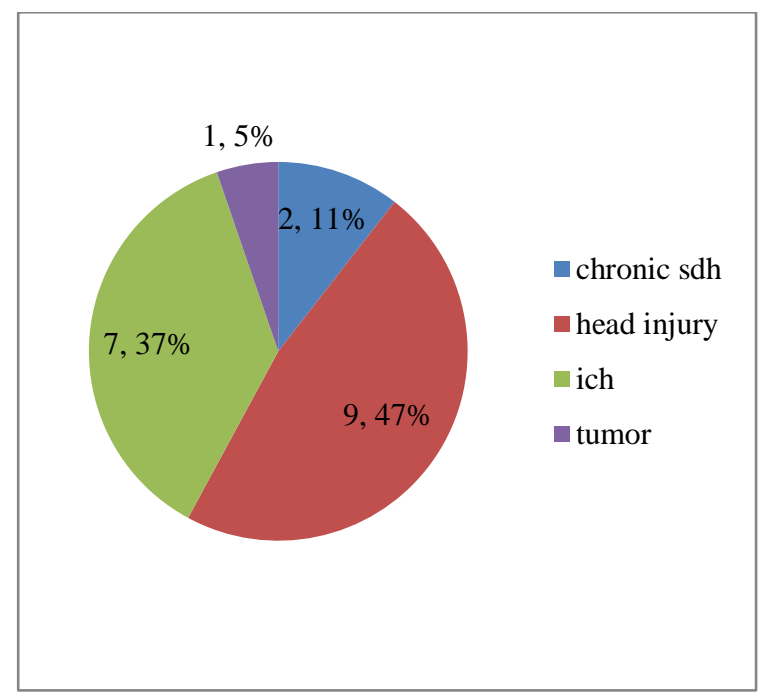

Figure 2: Distribution of diagnosis category
Table 1: Association of different variables with dural injury

\begin{tabular}{|c|c|c|c|c|c|}
\hline \multirow[t]{2}{*}{ Variables } & & \multicolumn{3}{|c|}{ Dural injury } & \multirow[t]{2}{*}{$\begin{array}{c}\mathbf{P} \\
\text { Value }\end{array}$} \\
\hline & & $\begin{array}{c}\text { No } \\
\text { Injury }\end{array}$ & $\begin{array}{c}\text { One burr } \\
\text { injury }\end{array}$ & $\begin{array}{c}\text { Two burr } \\
\text { injury }\end{array}$ & \\
\hline \multirow[t]{2}{*}{ Gender } & Female & 3 & 1 & 0 & \multirow{2}{*}{0.65} \\
\hline & Male & 12 & 1 & 2 & \\
\hline \multirow[t]{4}{*}{$\begin{array}{l}\text { Diagnosi } \\
\text { s } \\
\text { category }\end{array}$} & $\begin{array}{c}\text { chronic } \\
\mathrm{SDH}\end{array}$ & 2 & 0 & 0 & \multirow{4}{*}{0.55} \\
\hline & $\begin{array}{l}\text { Head } \\
\text { injury }\end{array}$ & 5 & 2 & 2 & \\
\hline & $\mathrm{ICH}$ & 7 & 0 & 0 & \\
\hline & Tumor & 1 & 0 & 0 & \\
\hline
\end{tabular}

Table 2: Correlation between number of burr and dural injury

\begin{tabular}{|c|c|c|c|}
\hline & & $\begin{array}{l}\text { Dural } \\
\text { injury }\end{array}$ & $\begin{array}{l}\text { Number of } \\
\text { burr }\end{array}$ \\
\hline \multirow[t]{4}{*}{ Dural injury } & Pearson & 1 & $.596^{* * *}$ \\
\hline & Correlation & & \\
\hline & $\begin{array}{l}\text { Sig. } \\
\text { tailed }\end{array}$ & & .007 \\
\hline & $\mathrm{N}$ & 19 & 19 \\
\hline \multirow{4}{*}{$\begin{array}{l}\text { Number } \\
\text { burr }\end{array}$} & Pearson & $.596^{* *}$ & 1 \\
\hline & Correlation & & \\
\hline & $\begin{array}{l}\text { Sig. } \\
\text { tailed) }\end{array}$ & .007 & \\
\hline & $\mathrm{N}$ & 19 & 19 \\
\hline
\end{tabular}

Historical evidence of trephination of skull was way back in the 1700 B.C where the survival following trephination were evident by bone growth in the trephined part of the skull..$^{4-8}$ There were various development in the past for creating a safe burr hole which initially started from manual trephination tool to recent motion guided electrical/ pneumatic drills. ${ }^{9,10}$ The evidence of dural injury was higher with manual drills which was significantly reduced with the modern tools. 10 Despite of using modern tools there were still few evidence of dural injury which mostly localized to the outer dural layer. ${ }^{1,2}$ In this study, there was $6.89 \%$ of dural injury which was localized to the outer dural layer among 87 numbers of burr holes made. Most of the dural injury is noted in elderly population in some of the literatures. ${ }^{1}$ However; this study didn't showed significant correlation between age and dural tear, which might be due to small sample size. 
As we know using the same electrical instrument will decrease their efficacy during its subsequent uses. Similarly, in this study there was significant association of number of burr holes made during the single use with dural injury; where higher the number of burrs, correlation showed higher was the dural injury.

\section{Conclusion}

There was no significant correlation between age and dural injury. However, significant correlation was seen between numbers of burr holes made during the procedure with dural injury.

\section{References}

1. Engelhardt M, Uhlenbruch S, Christmann A, Miede C, Eufinger H, Scholz M, Harders A, Schmieder K. Accidential Dural Tears Occurring during Supratentorial Craniotomy-A Prospective Analysis of Predisposing Factors in 100 Patients. Zentralblatt für Neurochirurgie. 2005 May;66(02):70-4.

2. Ito M, Sonokawa T, Mishina H, Sato K. Penetrating injury of the brain by the burr of a high-speed air drill during craniotomy: case report. Journal of clinical neuroscience. 2001 May 1;8(3):261-3.

3. Sahu RN, Das KK, Srivastava AK. Cranial Burr Hole. Manual of ICU Procedures. 2015 Aug 31:430.

4. Breasted JH. The Edwin Smith Surgical Papyrus: published in facsimile and hieroglyphic transliteration with translation and commentary in two volumes. Chicago: University of Chicago Press; 1930.

5. Elerick DV, Tyson RA, editors. Human paleopathology and related subjects: an international bibliography. San Diego Museum of Man; 1997.

6. Merbs C, Christensen NR, Tyson RA, Dyer Alcauskas ES. Catalogue of the Hrdlicka paleopathology collection.

7. Stone JL, Urcid J. Pre-columbian skull trepanation in North America. Trepanation. 2003:237.

8. Clower WT, Finger S. Discovering trepanation: the contribution of Paul Broca. Neurosurgery. 2001 Dec 1;49(6):1417-26.

9. Pait GT, Dennis MW, Laws Jr ER, Rizzoli HV, Azzam CJ. The history of the neurosurgical engine. Neurosurgery. 1991 Jan 1;28(1):111-29.

10. Dujovny MI, Gundamraj R, Misra M. Instrumentation Report: High power drill systems in neurosurgery. Neurological research. 1997 Dec 1;19(6):654-6. 